\title{
THE EFFECT OF CORPORATE IMAGE ON BRAND AWARENESS AND BRANG ATTITUDE
}

\author{
Didit Darmawan \\ Dosen Fakultas Ekonomi Universitas Mayjen Sungkono Mojokerto \\ Email.dr.diditdarmawan@gmail.com
}

\begin{abstract}
Various advancements and dynamics in the business world led to rapid developments in various industries. Corporate image is the main provision to survive in industrial competition. With the existence of a good corporate image, it is expected to increase brand awareness and brand attitude of the products circulating in the market. This study will examine the effect of corporate image on brand awareness and brand attitude. This study involved 100 respondents using an analytical tool in the form of simple linear regression with proof through t test. The results of the study show that the corporate's image significantly influences brand awareness and brand attitude.
\end{abstract}

\section{Keywords: Corporate Image, Brand Awareness, Brand Attitude}

\section{INTRODUCTION}

Promotion or marketing communication is one of the determinants of the success of a marketing program. Promotional activities can also disseminate information relating to the product. The company as a communicator who has given a message to the target market in this case the customer in hopes of a response or reaction. One response given by customers is how to image about the company and its product brands. Kotler and Armstrong (2014) explain the definition of image as a form of a set of beliefs, images and impressions that are attached to a person to a particular object such as a person, organization, or group of individuals. The form of an object in the form of an organization means the overall belief, description and perception of the organization as a manifestation of the image. The company's strategy to shape the image is generally carried out by creating communication and establishing effective relationships and providing an appreciation program for products by conducting promotions. The company hopes that promotional activities besides being able to introduce products to the public can also add interested people who want to try to use the products offered by the company. 
With the experience of products, consumers can be stimulated more easily to be able to use products repeatedly.

The image of the company is not just formed but requires a short period of time to form in the minds of consumers. One example is PT. Orang Tua Group. The brand of "Orang Tua" began from 1948. At that time the community accepted "Orang Tua" as one of the brands of wine made from wine which is claimed to be a traditional health drink. After years, people have known "Orang Tua" as a brand of Wine products. Therefore an effort is needed to renew the brand's impression in line with business development in the consumer goods industry. In the past 2004, the "Orang Tua" logo has undergone a change to strengthen efforts to instill an impression in the minds of consumers that "Orang Tua" are companies that are consumers of brand choices that are dynamic, energetic, youthful and proud of their employees. Over time, in general, dynamic business development and expansion of business units and new products have caused "Orang Tua" to have successfully entered various industrial groups, such as personal care, confectionery, health drink, wafers and biscuit, dairy products, jelly products, RTD tea and snack and nut. This company was originally known to produce traditional health drink products which later developed into producers of daily necessities.

Corporate image becomes a marketing element that must be the focus of the company because through a good corporate image will create an impression and emotional value in consumers, which will arise positive feelings when consuming the brand. And vice versa if a company has a bad impression according to consumers, it has a small opportunity to be bought by consumers for the products produced by the company.

In industries with intense competition like today, the existence of brands has an important role for the survival of the company. Brands are no longer seen as logos or symbols. The brand's position has become a set of values represented and offered by a product for its users. Brand awareness and attitude is crucial and this is influenced by the company's image. 
Brand awareness can be indicated as the level of consumer familiarity with a brand (Aaker, 1991). According to Rossiter and Percy (1987), brand awareness is the capacity of consumers to recognize brands among other brands. Keller (1993) states that brand awareness is a key component of brand value. According to him, efforts to design a brand awareness program through efforts involve brand review and brand acknowledgment. According to Aaker (1991), the level of brand awareness includes (a) brand recognition as the buyer's capacity to recognize a particular brand among others; (b) brand recall as a condition in which buyers are relied upon to provide brand names in the class of goods; and (c) top of mind as the first brand that can be reviewed by customers among certain product categories.

Brand attitude can be shown as an overall evaluation of consumers on the brand's ability to meet needs (Liu et al., 2012). Bagozzi et al. (1979) states that attitudes consist of various dimensions consisting of affective, behavioral, and cognitive dimensions. These dimensions can be shown through brand affection, purchase intention, and brand trust as the presentation of the affective, behavioral, and cognitive dimensions of brand attitudes (Wu and Wang, 2011). Consumer attitudes can be used to predict their purchase intentions and behavior (Bagozzi et al., 1979) which further influences brand loyalty.

With a good corporate image will shape the level of awareness of brand products of the company in a good order and consumer attitudes towards the brands produced by the company. Gray and Balmer (1998) explain that corporate image is generated by corporate identity, Kennedy (1977) found that corporate image depends on communication through the organization and corporate image related to tangible and intangible characteristics, for example functional characteristics, physical characteristics and emotional characteristics of the company. Martineau (1958) determined that corporate image includes functional quality and psychological attributes. Corporate images in service organizations include attributes, functional consequences, and symbolic meanings (Padgett and Allen, 1997). The positive thing that is able to develop a corporate image is through service, recognition and achievements of the company and the 
background or history of the company. This shows that the corporate image becomes the realization of the corporate identity that is formed in the minds of the target market.

This study will observe the effect of corporate image on brand awareness and brand attitude of PT. Orang Tua Group. Some people consider the corporate image of "Orang Tua" synonymous with wine-based drinks which are also considered as one alcoholic beverage. Based on these perceptions, the effect of the image of PT. Orang Tua Group towards brand awareness and brand attitude. The conceptual framework in this study is shown in Figure 1 below.

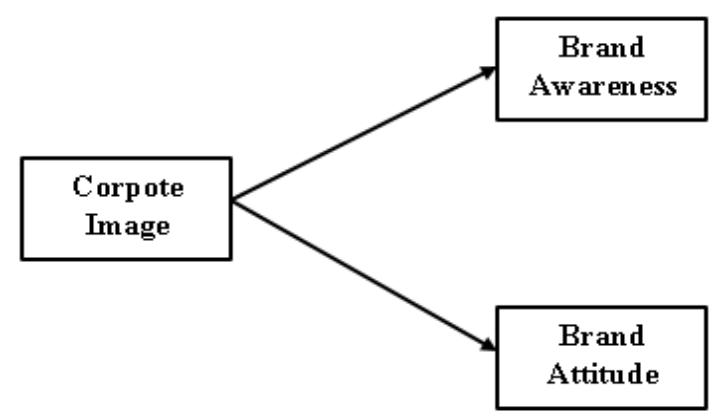

Figure 1 Research Conceptual Framework

Source: Processed by the author, 2018

\section{Research Hypothesis}

Based on the conceptual framework like Figure 1, the research hypothesis is set as follows.

1. Corporate image has a significant effect on the awareness of PT. Orang Tua Group

2. Corporate image has a significant effect on the brand attitude of PT. Orang Tua Group

\section{RESEARCH METHODS}

This explanatory study intends to explain the relationship in the form of the impact of independent variables on the dependent variable. The sampling technique in this study using the purposive sampling method and accidential sampling. The combination of the two methods is the selection of samples for anyone who accidentally met and according to criteria set by the researcher. It is 
emphasized that the sample must be in accordance with the conditions of the respondents determined by the researcher as a source. The population in this study were all product users from PT. Orang Tua Group in Surabaya city and the number is not known with certainty, 100 samples of respondents were used.

Research variables consisting of independent variables and dependent variables are described as follows. The independent variable is the corporate image. Corporate image is a collection of associations and consumer impressions of a company. The indicator is: (a) awareness of corporate names in the form of a statement: I know PT. Orang Tua Group; (b) corporate reputation with the form of statement: in my opinion, PT. Orang Tua Group is well known by the public; and (c) the impression of quality (afinity) with the form of statement: the brands of PT. Orang Tua Group gives a positive impression to consumers.

In this study there are two dependent variables. Brand Awareness (Y1) is the ability of a prospective buyer to remember the existence of a brand in a particular group or product category. The indicator is : (a) it's easy to remember, in the form of a statement: Brands produced by PT. Orang Tua Group is always remembered by consumers; (b) famous, in the form of a statement: Brands produced by PT. Orang Tua Group are well-known brands; and (c) always remember the brand, in the form of a statement: Brands produced by PT. Orang Tua Group always be the first brand to remember.

Brand Attitude (Y2) as the second dependent variable is a form of overall consumer evaluation of the brand and forms the basis that consumers use in their decisions and behavior. The indicator is : (a) interested, in the form of a statement: I am interested in using brands from PT. Orang Tua Group; (b) believe, in the form of a statement: I believe in the brands produced by PT. Orang Tua Group are brands that can satisfy users; and (c) positive impression with the form of statement: I like the brands produced by PT. Orang Tua Group.

The instrument in this study was a questionnaire. This questionnaire was designed using a Likert scale ordinal scale on the independent variable and the dependent variable including: (a) strongly agreed to be given a value of five; (b) agree to be given a value of four; (c) neither agree nor disagree given a value of 
three; (d) disagree given a value of two; (e) strongly disagree given a value of one. The data analysis technique used in analyzing the effect of independent variables on the dependent variable is a simple regression analysis with a formula: $\mathrm{Y}=\mathrm{a}+$ $\mathrm{bX}$ 1, where: $\mathrm{Y}$ is the dependent variable; $\mathrm{a}$ is the (constant) intercept value; $\mathrm{b}$ is the regression coefficient; and $\mathrm{X}$ is an independent variable. Regression Analysis with SPSS software. Test data to be carried out in this study is to test the validity, reliability, partial test ( $\mathrm{t}$ test) and $\mathrm{F}$ test of the primary data that has been processed.

The data proved valid if the calculated correlation data value is greater than the table correlation value. The calculated $r$ value from the SPSS output is indicated by the value of "corrected item total correlation". If the $r$ positive result is greater than 0.3 then the question item is valid. Reliability test to measure the accuracy of an instrument repeatedly to get consistent results. The reliability of a questionnaire occurs when the response is received consistently. The coefficient " $r$ " which is in the range from 0 to 1 and the value of $r<0.6>$ from 0.6 means that the question / variable is reliable. This means that the data obtained is feasible to be processed in further analysis. Normality test uses a normal probability plot. The t test is used to determine the magnitude of the effect of independent variables partially to explain variations in the dependent variable (Ghozali, 2005). The coefficient of determination (R2) to measure how much the contribution of the model to explain the variation of independent variables. The coefficient of determination is between zero and one. Large values have the meaning of independent variables able to explain the information needed to predict variations in the dependent variable.

\section{RESULTS AND DISCUSSION}

Description analysis is used to show the profile of the respondents used in this study based on gender, age, occupation, frequency of purchases. Respondents in this study were 100 and showed characteristics as shown in Table 1 below.

Table 1. Characteristics of respondents

\begin{tabular}{cccc} 
No & Characteristics & Description & Percentage \\
1 & Gender & Pria & $73 \%$ \\
\hline
\end{tabular}




\begin{tabular}{|c|c|c|c|}
\hline \multirow{4}{*}{2} & & Wanita & $27 \%$ \\
\hline & Age & $20-30$ tahun & $25 \%$ \\
\hline & & $30-40$ tahun & $29 \%$ \\
\hline & & 40 - 50 tahun & $32 \%$ \\
\hline \multirow{5}{*}{3} & & $50-60$ tahun & $9 \%$ \\
\hline & & $>60$ tahun & $4 \%$ \\
\hline & Frequency of purchases per & $1-3 x$ & $69 \%$ \\
\hline & month & $3-5 x$ & $24 \%$ \\
\hline & & $>5 x$ & $7 \%$ \\
\hline
\end{tabular}

Source: processed by SPSS

From Table 1 it can be stated that the respondents collected more men than women. As for the age range, it is relatively even in the range of 20 to 50 years. Thus the distribution of data is more in that age range. For the frequency of purchases from PT. Orang Tua Group, the most respondents are in the range of 1 to 3 purchases during a month.

\begin{tabular}{ccc} 
Table2 Validity Test & & \\
\hline Variables & Indikator & corrected item-total correlation \\
Corporate Image & X.1 & 0,632 \\
& X.2 & 0,610 \\
& X.3 & 0,704 \\
X.4 & 0,881 \\
Brand Awareness & X.5 & 0,502 \\
& Y.6 & 0,778 \\
& Y12 & 0,495 \\
Y13 & 0,303 \\
Brand Attitude & Y14 & 0,567 \\
& Y15 & 0,441 \\
& Y16 & 0,482 \\
& Y21 & 0,416 \\
& Y22 & 0,805 \\
& Y23 & 0,790 \\
& Y24 & 0,775 \\
& Y25 & 0,814 \\
& Y26 & 0,847 \\
& & 0,739
\end{tabular}

Source: processed by SPSS

Next is to test the validity of each variable indicator. To test the validity of the data, researchers pay attention to the corrected item-total correlation (r) which shows the data validity coefficient. Table 2 shows the results of the validation of each variable indicator. In Table 2, it is known that each question item from X1 to $\mathrm{X} 6$ is proven to have a value of corrected item total correlation greater than 0.3 . 
So even in the question items on the dependent variables, Y1 and Y2. Thus in addition to the reliability test, the validity test is fulfilled. The list of questions about the research variables is reliable or reliable and valid for further analysis.

Reliability test results as shown in Table 3. According to Ghozali (2005), a construct is said to be reliable if it gives Cronbach Alpha> 0.6. The results of the reliability test in this study indicate acceptable values on each indicator variable.

Table 3 Reliability Test

$\begin{array}{ccc}\text { Variables } & \text { Alpha Cronbach } & \text { Cut of Value } \\ \text { X - Corporate Image } & 0.689 & 0.60 \\ \text { Y1 - Brand Awareness } & 0.688 & 0.60 \\ \text { Y2 - Brand Attitude } & 0.712 & 0.60\end{array}$

Source: processed by SPSS

The classic assumption test is done by normality test, autocorrelation and heteroscedasticity. In the normality test the two dependent variables are shown in Figure 2. The image shows the points that spread around the diagonal and the spread follows the direction of the diagonal line. This shows that the existing data has been normally distributed.
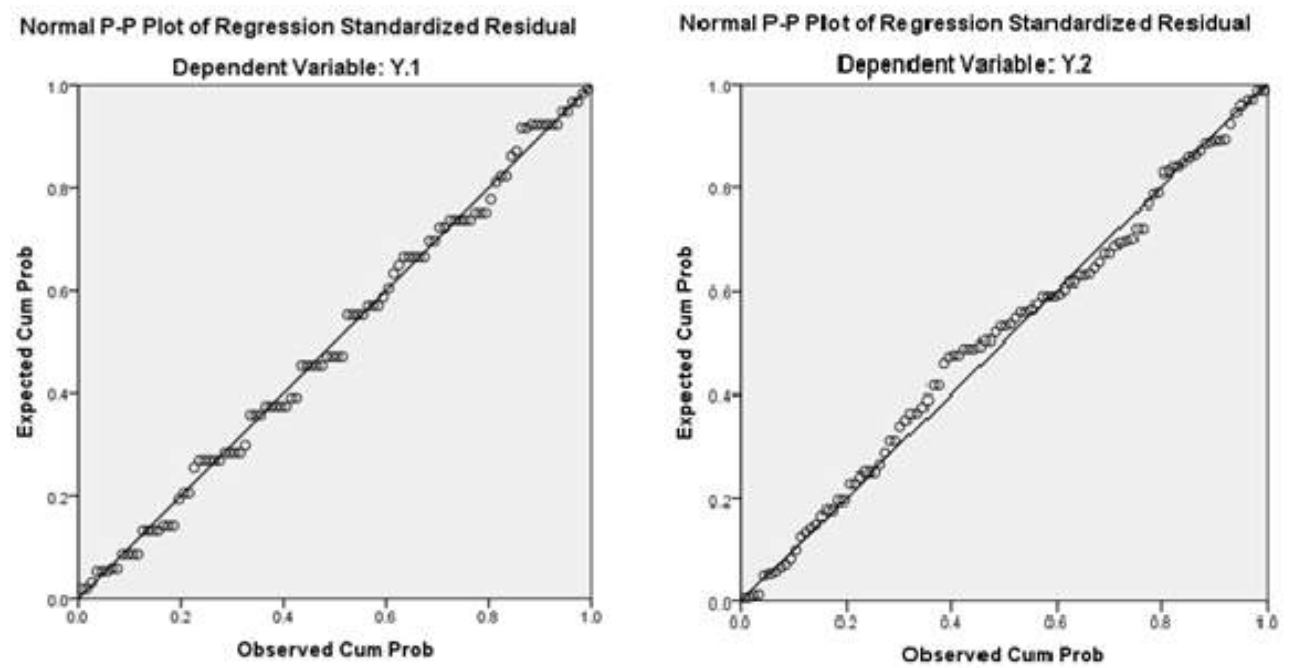

Figure 2 Normal Probability Plot Source: processed by SPSS

In the autocorrelation test, the Durbin-Watson number (DW Test) was 1.988 (Y1) and 1.865 (Y2). This shows that there is no autocorrelation. In the regression 
model there is no correlation between bullies in period $t$ with errors in period $t-1$ (before).

Heteroscedasticity test to determine the level of residual diversity that is not the same for all observations. In Figure 3 shows that the points on the scatterplot are scattered and are located on each part on the $\mathrm{Y}$ axis. This means that there is no heteroscedasticity.
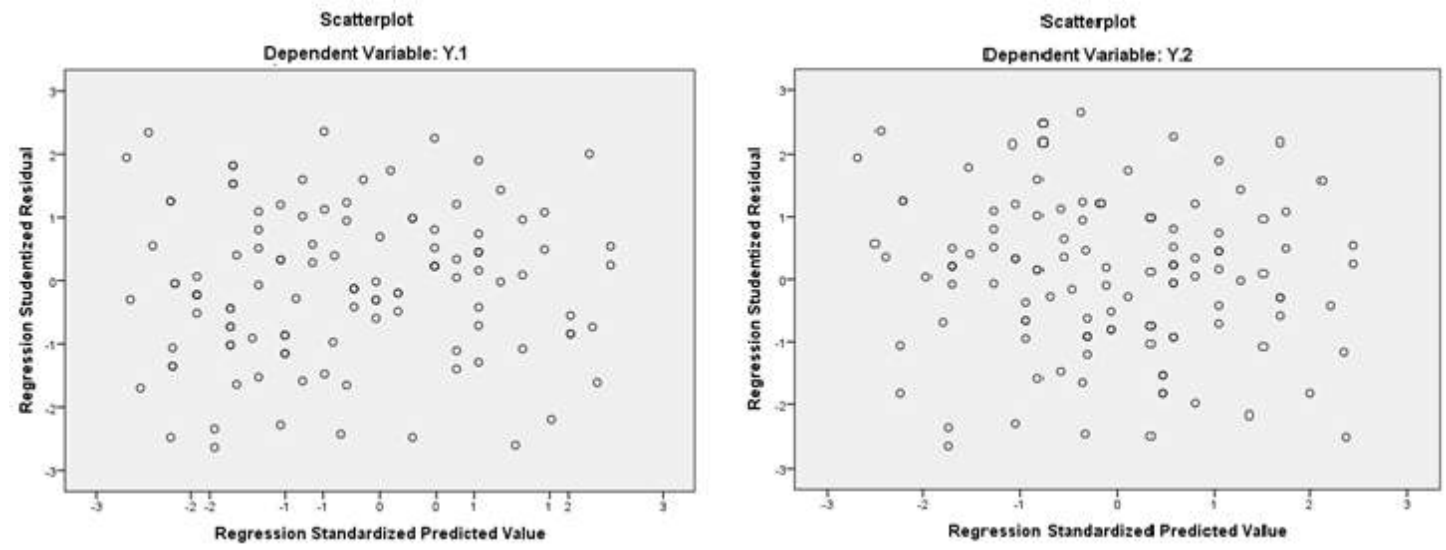

Figure 3 Normal Probability Plot Source: processed by SPSS

After the data has been valid and reliable and fulfills the classical assumption requirements, hypothesis testing is done. To find out the effect of independent variables, quantitative analysis was used with linear regression methods. In linear regression analysis will be done by $\mathrm{t}$ test to prove the truth of the hypothesis. The first hypothesis is that corporate image influences brand awareness. Based on the results of calculations using SPSS the results obtained in Table 4 below.

Table 4. $\mathrm{t}$ test (corporate images on brand awareness)

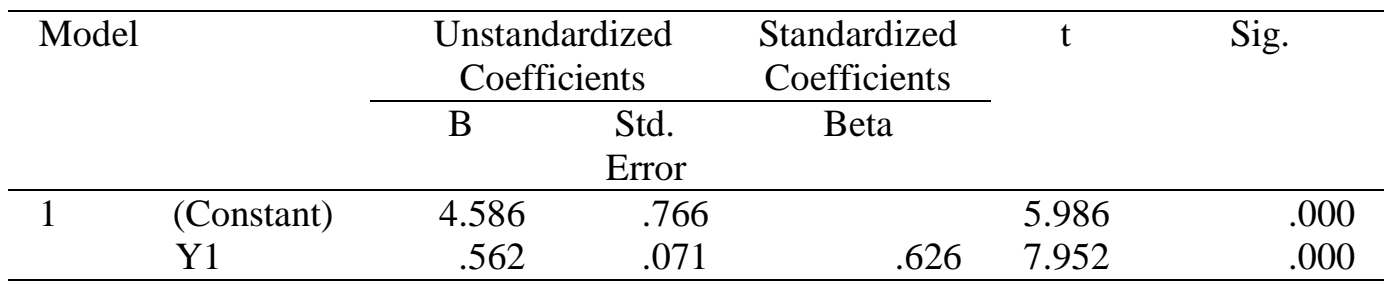

Source: processed by SPSS

Based on Table 4 shows that there is an influence of corporate image on brand awareness. The influence shows that the corporate image variable as the 
independent variable changes in line with the change in brand awareness as the dependent variable.

From Table 4 it can be explained that the brand awareness variable continues to increase by 4.586 along with the more fulfilled probability of corporate image $(\mathrm{X})$ of 0.000 . This means that the independent variable ie corporate image at the real level (5\%) has a significant influence on brand awareness. The regression equation produced based on Table 4.3 is as follows: Y1 $=4.586+0.562 \mathrm{X}+\mathrm{e}$.

Thus the first hypothesis in this study which states that corporate image has a significant effect on brand awareness of PT. Orang Tua Group, can be accepted and proven correct.

Next is the second hypothesis test which states that corporate image has a significant effect on the brand attitude of PT. Orang Tua Group. Table 5 shows the results of SPSS.

Table $5 \mathrm{t}$ test (corporate images on brand attitudes)

\begin{tabular}{llrrrrr}
\hline Model & \multicolumn{2}{c}{$\begin{array}{c}\text { Unstandardized } \\
\text { Coefficients }\end{array}$} & \multicolumn{2}{c}{$\begin{array}{c}\text { Standardized } \\
\text { Coefficients }\end{array}$} & & \multirow{2}{*}{ S } \\
& & B & Std. Error & Beta & & \\
\cline { 3 - 4 } & (Constant) & .4 & .4 & & 1.0 & .3 \\
& & 01 & 01 & & 01 & 19 \\
& Y2 & .9 & .0 & .93 & 25. & .0 \\
& 55 & 37 & 3 & 667 & 00 \\
\hline
\end{tabular}

Source: processed by SPSS

Based on Table 5 shows that there is an influence of corporate image on brand attitude. The influence shows that the corporate image variable as the independent variable changes in line with the change in brand attitude as the dependent variable. From Table 5 it can be explained that the brand attitude variable continues to increase by 0.401 along with the more fulfilled probability of corporate image $(\mathrm{X})$ of 0.000 . This means that the company image variable at the real level (5\%) has a significant effect on brand attitudes. The regression equation produced based on Table 5 is as follows: $\mathrm{Y} 2=0.401+0.955 \mathrm{X}+\mathrm{e}$.

Thus the second hypothesis in this study which states that the corporate image has a significant effect on the brand attitude of PT. Orang Tua Group can be accepted and proven correct. 
The coefficient of determination (R2) essentially measures how far the model's ability to explain the variation of the independent variable. The coefficient of determination is between zero and one (Ghozali 2005). The coefficient of determination $\left(\mathrm{R}^{2}\right)$ for the influence of corporate image on brand awareness can be seen from the following table.

Table 6 Model Summary (corporate images on brand awareness)

\begin{tabular}{llrrr}
\hline Model & R & R Square & Adjusted R Square & Std. Error of the Estimate \\
\hline 1 & $.626^{\text {a }}$ & .392 & .386 & .95586 \\
\hline
\end{tabular}

Source: processed by SPSS

From the table, the SPSS output from the R Square summary model is 0.392. That means only $39.2 \%$ of brand awareness (Y1) can be explained by corporate image variables. While the remaining $60.8 \%$ is explained by other causes. While the coefficient of determination $\left(\mathrm{R}^{2}\right)$ for the influence of corporate image on brand attitude can be shown from the following table.

Table 7 Model Summary (corporate images on brand attitudes)

\begin{tabular}{llrrr}
\hline Model & R & R Square & Adjusted R Square & Std. Error of the Estimate \\
\hline 1 & $.933^{\mathrm{a}}$ & .871 & .869 & .44119 \\
\hline
\end{tabular}

Source: processed by SPSS

From the table, it is shown the SPSS output model, the sum of R Square is 0.871 . This means that only $87.1 \%$ of the variation in brand attitude (Y2) can be explained by corporate image variables. While the remaining $13.9 \%$ is explained by other reasons.

Based on the analysis of the research results obtained several findings as explained as follows. The first hypothesis in this study is that corporate image has a significant effect on the awareness of PT. Orang Tua Group. From the results of the SPSS output it was found that the probability level was 0.000 , which means below $5 \%$ which indicates that there is a significant influence of corporate image on brand awareness. Thus the first hypothesis in this study proved correct. A corporation such as PT. Orang Tua Group must have the power to distinguish themselves from other corporations or competitors. With the existence of a good corporate image will form a level of awareness or good knowledge of each brand that is produced and can be known by consumers. 
The second hypothesis in this study is that corporate image has a significant effect on the brand attitude of PT. Orang Tua Group. From the results of the SPSS output it was found that the probability level was 0,000 which means below 5\% which indicates that there is a significant influence of corporate image on brand attitudes. Thus the second hypothesis in this study proved correct. Brands have an important role. This is because the existence of a brand is connected with promises and expectations so that it becomes a corridor to connect between consumer expectations and company promises. Prestigious brands have strong brand equity. Brand awareness and attitude are important elements of brand equity. The development of corporate image is one of the biggest challenges in increasing product brand equity because handling corporate image is one method in formulating a positioning which is a process to convince consumers that the brands can compete with other brands, because they have a unique and superior value so they can enter the minds of consumers. Based on the results of this study, to create a high level of awareness and a positive brand attitude, the corporation must have a good corporate image according to the perceptions of its customers.

\section{CONCLUSIONS}

From the results of the analysis of the results of the research and discussion, things that were the main things were obtained to be concluded as concluding in this research report. The following are the results of this study. (1) corporate image significantly influences the brand awareness of PT. Orang Tua Group; (2) corporate image significantly influences the brand awareness of PT. Orang Tua Group.

The researcher suggests some of the following. Corporate image is very important to develop the strength of each brand of product produced by a corporation such as PT. Orang Tua Group. Thus PT. Orang Tua Group needs to pay attention to marketing communication activities specifically to develop the corporate image. If this is done successfully it will have a positive impact on the development of the strength of its product brand. Brand strength development can be a better level of brand awareness from consumers. One of them is to strengthen 
market position and increase knowledge about product brands. In addition, the development of brand strength can be in the form of an attitude towards a brand that will be better and positive. A good brand awareness and attitude will open up more opportunities for indications of brand purchases and subsequently affect the expansion of the number of consumer products. From the results of this study it is recommended for further research to involve other variables as independent variables or as dependent variables such as marketing communication, price, product quality and so on.

\section{REFERENCES}

Aaker, D. A. 1991. Managing Brand Equity Capitalizing on The Value of a Brand Name. New York: Free Press

Andreassen, Wallin \& Lindestad. 1997. The Impact of Corporate Image on Quality, Customer Satisfaction, and Loyalty for Customer with Varying Degrees of Service Expertise. The International Journal of Service Industry Management

Bagozzi, R.P., A.M. Tybout, C.S. Craig, \& B. Sternthal. 1979. The Construct Validity of The Tripartite Classification of Attitudes. Journal of Marketing Research, 16(1), 88-95.

Ferdinand, Augusty. 2006. Metode Penelitian Manajemen. Semarang: Badan Penerbit UNDIP

Ghozali, Imam. 2005. Aplikasi Analisis Multivariate dengan Program SPSS. Semarang: Badan Penerbit Universitas Diponegoro

Grunig, J. 2003. Image and Substance: From Symbolic to Behavioural Relationships, in Balmer, J.M.T., Greyser, S.A. (Eds), Revealing the Corporation: Perspectives on Identity, Image, Reputation, Corporate Branding, and CorporateLevel Marketing, Routledge, New York, NY.

Gray E R \& Balmer J M T. 1998. Managing Corporate Image and Corporate Reputation. Long Range Planning, Vol. 31, No. 5, pp. 695- 702.

Hoyer, W.D., D.J. MacInnis \& R. Pieters. 2013. Consumer Behavior, 6th international edn., South-Western Cengage Learning, Mason, Ohio.

Kotler, Philip. \& Gary Armstrong. 2014. Principle Of Marketing, 15th edition. New Jersey: Pearson Prentice Hall.

Kennedy, S.H. 1977. Nurturing Corporate Image. European Journal of Marketing, Vol. 11 No. 3, pp. 120-64.

Keller, Kevin Lane. 1993. Conceptualizing, Measuring and Managing CustomersBased Brand Equity. Journal of Marketing Management 57, 1-12.

Kotler Philip \& Kevin Lane Keller. 2012. Marketing Management, 14 th. ed, Pearson Education, Inc., New Jersey.

Liu, F., J. Li, D. Mizerski, \& H. Soh. 2012. Self-congruity, Brand Attitude, and Brand Loyalty: A Study on Luxury Brands. European Journal of Marketing, 46(7/8), 922-937. 
Loudon, David L \& Albert J. Della Bitta. 2004. Consumer Behavior Concepts and Appications. Third Edition Singapore, MC Graw Hill Inc.

Martineau, P.1958. Sharper Focus for the Corporate Image. Harvard Business Review, Vol. November/ December, pp. 49-58.

Padgett, D. \& D. Allen. 1997. Communicating Experiences: A Narrative Approach to Creating Service Brand Image. Journal of Advertising, Vol. 26, No. 4, pp. 49- 62.

Percy, Larry, \& John R. Rossiter. A model of Brand Awareness \& Brand Attitude Advertising Strategies. Psychology \& Marketing 9.4 (2006): 263-274.

Rossiter, RJ, \& L. Percy. 1987. Advertising and Promotion Management. McGraw-Hill, New York, n.y.

Villanova, L., G.M. Zinkhan, \& M.R. Hyman. 1990. On Defining and Measuring Store Image, in B.J. Dunlap (ed.) Proceedings of the Thirteenth Annual Conference of the Academy of Marketing Science, April, pp. 466-70. New Orleans, LA: Academy of Marketing Science.

Wu, P.C.S. \& Y.C. Wang. 2011. The Influences of Electronic Word-of-Mouth Message Appeal and Message Source Credibility on Brand Attitude. Asia Pacific Journal of Marketing and Logistics, 23(4), 448-472. 